\title{
Yield enhancement of chilli through integrated crop management in Kala- buragi district of Karnataka, India
}

\author{
Raju, G. Teggelli ${ }^{*}$, Siddappa ${ }^{2}$, Zaheer Ahamad ${ }^{3}$ and Anand Naik ${ }^{4}$ \\ ${ }^{1}$ Department of Agricultural Entomology, Krishi Vigyan Kendra, Kalaburagi-585101 (Karnataka), INDIA \\ ${ }^{2}$ Department of Horticulture, Krishi Vigyan Kendra, Kalaburagi-585101 (Karnataka), INDIA \\ ${ }^{3}$ Department of Plant Pathology, Krishi Vigyan Kendra, Kalaburagi-585101 (Karnataka), INDIA \\ ${ }^{4}$ Department of Soil Science and Agricultural Chemistry, Krishi Vigyan Kendra, Kalaburagi-585101 (Karnataka), INDIA \\ *Corresponding author. E-mail: raju.teggelli@gmail.com
}

Received: April 30, 2015; Revised received: October 7, 2015; Accepted: November 6, 2015

\begin{abstract}
One of the major reasons of low productivity in chilli is the lack of technical knowledge of the farmers about judicious and timely implementation of the management strategies against the major biotic stresses (insect pests and diseases) which ultimately reduce its return. Considering the integrated crop management on need based plant protection in vegetables was conducted in farmer's fields at different villages of the Kalaburagi district, under northern part of Karnataka, during the period from 2011-12 to 2013-14 show the productivity potential and profitability of improved technologies. The results showed that, on an average the highest yield achieved by adopting integrated crop management was 260.17 quintals ha $^{-1}$, whereas the corresponding yield ranged under farmer's practices was to 235.243 quintals ha $^{-1}$ of green chillies. Adoption of integrated crop management will increase the yield $10.56 \%$ over farmer practices. The average technological gap, extension gap and technological index were noticed 139.83 quintals ha ${ }^{-1}, 24.92$ quintals ha ${ }^{-1}$ and $34.95 \%$ respectively. The economics of data indicated that an average of Rs. 1,64,500 $\mathrm{ha}^{-1}$ was recorded net profit under recommended practices while it was Rs $129976.7 \mathrm{ha}^{-1}$ under $^{-1}$ farmer practices. Cost benefit ratio was 3.07 under demonstration, while it was 2.35 under farmer practices. Practicing of integrated crop management with improved technologies will improve the farmer socio-economical level.
\end{abstract}

Keywords: Chilli, Economics, Extension gap, Technology gap, Technology index

\section{INTRODUCTION}

Chilli (Capsicum annum L.) a tropical and subtropical crop is one of the major vegetable and spice crop grown in India both as green and dry chilli. Among various spices produced in India per capita consumption is the highest for chillies. India is the world's largest producer, consumer and exporter of chili (Agrocrops, 2013). The states Andhra Pradesh, Karnataka, Maharashtra, Orissa, Tamil Nadu and West Bengal are leading in chilli cultivation. During 2008-09 the area under the crop was 69,880 ha with an annual production of 94500 tonnes with the productivity of $1.3 \mathrm{t} \mathrm{ha}^{-1}$ (Vanitha et al., 2013) in Karnataka.

The main reasons for low yield in chilli are low coverage of high yielding varieties/hybrids, heavy incidence of pest and disease and lack of adoption of scientific package of practices and improved technologies (Indira et al., 2001). The package of improved technologies comprising high yielding hybrid seeds, integrated balanced nutrient management and proper plant protection measures were used as per package and practices of each crops. The cross sectional data on yield of chilli have been collected from the demonstration trials. In addition to this, data on farmer's prac- tices have also been collected. Yield of the demonstration trials and potential yield of the chilli compared to estimate the yield. The improved technology developed by research institutes was also found to be financially attractive. Yet adoption levels for several components of the improved technology were low emphasizing the need for better dissemination. Several biotic, a-biotic and socio-economic constraints inhibit exploitation of the yield potential (Rabindra et al., 2007). The Kalaburagi district in northern Karnataka has sizable area under chilli cultivation but the productivity is low. The low productivity of chilli crops is not only threat to economic security of millions small and marginal farmers but also to the world trade of chilli hitherto our country had the domination. Keeping the above points in view the integrated crop management (ICM) on chilli was initiated with objective of showing the increasing the productive potentials of the improved production technologies under real farm situations over local farmer's practices under Kalaburagi district of Karnataka .

\section{MATERIALS AND METHODS}

The present study was conducted by the Krishi Vigyan 
Table 1. Impact of integrated crop management on realization of productivity and potential of chilli under real farm situation.

\begin{tabular}{lcccccc}
\hline Year & $\begin{array}{c}\text { Area } \\
\text { (Ha) }\end{array}$ & $\begin{array}{c}\text { No. of } \\
\text { demonstrations }\end{array}$ & $\begin{array}{c}\text { Potential } \\
\text { yield }\end{array}$ & $\begin{array}{c}\text { Yield q ha } \\
\text { Demonstration } \\
\text { yield }\end{array}$ & $\begin{array}{c}\text { Farmers } \\
\text { practices }\end{array}$ & $\begin{array}{c}\text { \% Increase in yield over } \\
\text { farmer practice }\end{array}$ \\
\hline $2011-12$ & 10 & 25 & 400 & 226 & 206 & 9.7 \\
$2012-13$ & 5 & 12 & 400 & 275 & 244.23 & 12.6 \\
$2013-14$ & 5 & 12 & 400 & 279.5 & 255.5 & 9.4 \\
Average & & & 400 & 260.17 & 235.24 & 10.56 \\
Total & 20 & 49 & & & & \\
\hline
\end{tabular}

Kendra, Kalaburagi under University of Agricultural Sciences, Raichur. The field trials were conducted for consecutive years during the period from 2011-12 to 2013-14 at different villages of Kalaburagi district of Karnataka. The Kalaburagi District situated between $17^{\circ} 19^{\prime}$ North and $76^{\circ} 54^{\prime}$ East longitude. The soil of farmers field is medium black soil with $\mathrm{pH}(6.8-7.5)$ EC (0.24-0.36 $\left.\mathrm{dSm}^{-1}\right)$, available $\mathrm{N}\left(250-24 \mathrm{~kg} \mathrm{ha}^{-1}\right)$, available P $\left(75 \mathrm{~kg} \mathrm{ha}^{-1}\right)$ and available $\mathrm{K}\left(390 \mathrm{~kg} \mathrm{ha}^{-1}\right)$. The treatments Farmers practices and Recommended practices with integrated crop management. The whole package approach demonstrated to the farmers through integrated crop management field trails included the components like improved variety, seed rate, spacing INM and IPM. The data generated, in full package technology was utilized for calculating the technological index, technology and extension gaps using the formulae given by Kadian et al. (1997).

(1) $\%$ YIOFP ${ }^{*}=$ Average demonstration yield farmer's average plot yield/ Farmer's avg. plot yield

*YIOFP $=$ Yield increase over farmers practice

(2) Technological gap = Potential yield-Demonstration yield

(3) Extension gap= Demonstration yield-Farmers yield

(4)Technology index $=$ Potential yield - Demonstration yield/ Potential Yield $\times 100$

\section{RESULTS AND DISCUSSION}

A comparison of productivity levels between improved practices in demonstration trials and farmer's practices is shown in table 1. During the study period it was observed that the adoption of improved production technologies in demonstration trials has increased the yield over the farmer's practices.

Crop performance and yield: The performance of chilli owing to the adoption of improved technologies assessed over a period of three years and presented in table 1 reveal that, the effect of improved technologies earmarks the productivity sustainability of chilli production in the black soils region of southern India. The data in table 1 revealed that the average yield level of $260.17 \mathrm{q} \mathrm{ha} 1$ and $10.5 \%$ yields increased over farmers practice. Similar findings were reported by Ranjeet Singh et al (2011) in chilli, brinjal and tomato through front line demonstrations in Rajasthan.

Yield gaps: The data on table 2 indicates that technological gap, extension gap and technological index of integrated crop management in chilli through improved technologies. The yield gaps in the present study were categorized into technological gap and extension gaps. The average technological gap and extension gap was noticed $139.83 \mathrm{q} \mathrm{ha}^{-1}$ and $24.92 \mathrm{q} \mathrm{ha}^{-1}$ respectively, during the period from 2011-12 to 2013-14. Generally, the technological and extension gap appears even if the integrated crop management is conducted under the strict supervision of the scientists in the farmers' fields. This may be attributed mainly due to lack of high yielding varieties, irrigation facilities, variation in the soil fertility status, non congenial weather conditions and local specific management problems faced for the attainment of potential and demonstration yields. Therefore, location specific recommendations are necessary to a bridge the gap besides strengthening of irrigation facilities, use of high yielding varieties, in the region. The higher extension gap indicates that

Table 2. Technological gap, extension gap and technological index of the respondents.

\begin{tabular}{lcccc}
\hline Year & Area(Ha) & Technological gap $\left(\mathbf{q} \mathbf{~ h a}^{-\mathbf{1}}\right)$ & Extension gap $\left(\mathbf{q} \mathbf{~ h a}^{-\mathbf{1}}\right)$ & Technological index (\%) \\
\hline $2011-12$ & 10 & 174 & 20 & 43.50 \\
$2012-13$ & 5 & 125 & 30.77 & 31.25 \\
$2013-14$ & 5 & 120.5 & 24 & 30.13 \\
Average & & 139.83 & 24.92 & 34.95 \\
\hline
\end{tabular}

Table 3. Impact of integrated crop management on economics of chilli under real farm situation.

\begin{tabular}{|c|c|c|c|c|c|c|c|c|}
\hline \multirow[b]{2}{*}{ Year } & \multicolumn{2}{|c|}{ Cost of cultivation $\left(\mathrm{Rs} \mathrm{ha}^{-1}\right)$} & \multicolumn{2}{|c|}{ Gross return $\left(\mathrm{Rs} \mathrm{ha}^{-1}\right)$} & \multicolumn{2}{|c|}{ Net return $\left(\mathrm{Rs} \mathrm{ha}^{-1}\right)$} & \multicolumn{2}{|c|}{ BCR } \\
\hline & Demo & Farmer practice & Demo & $\begin{array}{c}\text { Farmer prac- } \\
\text { tice }\end{array}$ & Demo & $\begin{array}{l}\text { Farmer } \\
\text { practice }\end{array}$ & Demo & $\begin{array}{l}\text { Farmer } \\
\text { practice }\end{array}$ \\
\hline $2011-12$ & 26103 & 24000 & 81703 & 57600 & 55600 & 33600 & $1: 2.13$ & $1: 1.4$ \\
\hline $2012-13$ & 59713 & 58762 & 247213 & 204492 & 187500 & 145730 & $1: 3.14$ & $1: 2.48$ \\
\hline $2013-14$ & 63553 & 66018 & 313953 & 276618 & 250400 & 210600 & $1: 3.94$ & $1: 3.19$ \\
\hline Average & 53583 & 55309 & 218083 & 185284 & 164500 & 129976.7 & $1: 3.07$ & $1: 2.35$ \\
\hline
\end{tabular}


there is a strong need to motivate the farmers for adoption of improved technologies over their local practices.

Technology index: Technology index indicates the feasibility of the evolved technology in the farmer's fields. Lower the value of technology index, higher is the feasibility of the improved technology. Technology index varied from 43.50 to $30.13 \%$ in the chilli during the period from 2011-12 to 2013-14 three years of the study. This indicates that a strong gap exists between the generated technologies at the research institution and disseminated at the farmer's field. The findings of the present study technology index are in line with the findings of Hiremath and Nagaraju (2009) in onion. Introduction of high yielding varieties and demonstration of improved technology through integrated crop management on chilli would eventually lead to higher adoption among farmers in the region.

Economics of cultivation: Data in table 3 reveal that the cost involved in the adoption of improved technology in chilli varied and was more profitable. The average net return of demonstration field is 1,64,500 Rs $\mathrm{ha}^{-1}$ where as $1,29,976.7 \mathrm{Rs} \mathrm{ha}^{-1}$ under farmers practices. The mean B: C ratio was 3.07 and 2.35 for the demonstration field and farmer's practices, respectively, were similar findings of Singh (2000) in solanaceous vegetables. The economic analysis indicates that use of improved technology in chilli would substantially increase the income as well as livelihood of the farming community of Kalaburagi district of Karnataka.

\section{Conclusion}

It is concluded from the study that there exists a wide gap between the potential and demonstration yields in chilli mainly due to technology and extension gaps.
The study highlights that by adoption of improved technology, chilli productivity and profitability can be improved greatly even under farming situations and adverse weather conditions of Kalaburagi district. The improved technology has also shown potential to increase the yield of chilli. The adoption of improved technology besides strengthening improved technologies would help resource poor farmers to improve their livelihood and diversify their farming systems.

\section{REFERENCES}

Agrocrops.com. (2013). Indian chilli, chilli India, Indian chilli exporters, Indian Red Dry Chilli.

Hiremath, S. M. and Nagaraju, M. V. (2009). Evaluation of frontline demonstration trials on onion in Haveri district of Karnataka. Karnataka J. Agric. Sci., 22 (5): $1092-$ 1093.

Indira, P., Gopalkrishnan, T. R. and Peter, P. V. (2001). Spices in India. Paper presented In: Silver Jubilee Seminar on Spices, Indian Inst. Spice Res., Calicut, pp: 143152.

Kadian, K. S., Sharma, R and Sharma, A. K. (1997). Evaluation of frontline demonstration trials on oilseeds in kangra valley of Himachal Pradesh. Annals of Agriculture Research, 18 (1):40-43.

Rabindra, R. J., Sunil, J. and Veenakumari, K.. (2007) Biological control of insect pests of oilseeds in India, In changing global vegetable oil scenario: Issue and challenges before India (Ed Hedge DM), Indian Society of Oilseeds Research, Hyderabad, 101-142.

Ranjeet Singh, R. L. Soni, Virendra Singhand H. L. Bugalia, (2011). Dissemination of improved production technologies of solanaceous vegetables in banswara district of rajasthan through frontline demonstrations. Rajastan Journal of Extension Education, 19: 97-100.

Singh, D. K. (2000). Evaluation of different demonstration trials on solanaceous vegetables in Baran district of Rajasthan. Annals of Agricultural Research, 21 (4): 572 -574 .

Vanitha, S. M., Chaurasia, S. N. S., Singh, P. M. and Naik, P. S. (2013). Vegetable Statistics Technical Bulletin No. 51, IIVR, Varanasi, pp. 250. 